\title{
Metals in Metal Salts: A Copper Mirror Demonstration
}

Robert D. Pike

William \& Mary, rdpike@wm.edu

Follow this and additional works at: https://scholarworks.wm.edu/aspubs

Part of the Chemistry Commons

\section{Recommended Citation}

Pike, Robert D., Metals in Metal Salts: A Copper Mirror Demonstration (2010). Journal of Chemical Education, 87(10), 1062-1063.

https://doi.org/10.1021/ed1000075

This Article is brought to you for free and open access by the Arts and Sciences at W\&M ScholarWorks. It has been accepted for inclusion in Arts \& Sciences Articles by an authorized administrator of W\&M ScholarWorks. For more information, please contact scholarworks@wm.edu. 


\title{
Metals in Metal Salts: A Copper Mirror Demonstration
}

\author{
Robert D. Pike \\ Department of Chemistry, College of William and Mary, \\ P.O. Box 8795, Williamsburg, VA 23187-8795
}

Abstract: A simple lecture demonstration is described to show the latent presence of metal atoms in a metal salt. Copper(II) formate tetrahydrate is heated in a round bottom flask forming a high-quality copper mirror.

Keywords: metal, copper, reduction, ionic compound, decomposition. 


\title{
Metals in Metal Salts: A Copper Mirror Demonstration
}

\author{
Robert D. Pike \\ Department of Chemistry, College of William and Mary, \\ P.O. Box 8795, Williamsburg, VA 23187-8795
}

The presence of metal within an ionic metal salt is usually taken as an assumption in high school and college chemical education. Several laboratory experiments that demonstrate or even quantify the content of metal within metal compounds have been published in this Journal (1-6). In addition, there are a variety of high school and collegelevel experiments involving the redox chemistry of copper in pennies $(7,8)$. However, none of these experiments is readily amenable to a simple lecture demonstration that can accompany initial discussions of ionic compounds. Consideration of ionic substances is important in both high school and college-level introductory chemistry courses. Cations in all common ionic compounds, except ammonium salts, are metal ions. Demonstration of the latent presence of metal within a salt via reduction of the metal cation affords a visual touchstone for this important concept.

A convenient method for the reduction of metal salts would involve an anion that easily undergoes reductive elimination, a readily reducible metal ion, and would produce a readily identifiable metallic residue. All of these characteristics are fulfilled by the use of copper(II) formate tetrahydrate. The thermal decomposition of this salt is described in equation (1). 


$$
\mathrm{Cu}\left(\mathrm{O}_{2} \mathrm{CH}\right)_{2} \bullet 4 \mathrm{H}_{2} \mathrm{O}(\mathrm{s}) \rightarrow \mathrm{Cu}(\mathrm{s})+5 \mathrm{H}_{2} \mathrm{O}(\mathrm{g})+\mathrm{CO}_{2}(\mathrm{~g})+\mathrm{CO}(\mathrm{g})
$$

The formation of a copper mirror from copper(II) formate as described in equation (1) was first reported in 1947 (9); copper mirrors generated under inert atmosphere have been used as high-surface-area reducing agents for organic reactions (10). A related demonstration has been reported in a relatively obscure German-language journal (11).

\section{Materials}

- Copper(II) formate tetrahydrate [5893-61-8]

- $250 \mathrm{~mL}$ Borosilicate glass round bottom flask

- Three-prong clamp (without vinyl or rubber sleeves)

- Meeker burner and gas supply

- Spatula

- Wire gauze

- Nitric acid (for clean-up)

- A fire extinguisher should be readily available during any demonstration involving flames

\section{Preparation and Presentation}

Approximately $3 \mathrm{~g}$ of $\mathrm{Cu}\left(\mathrm{O}_{2} \mathrm{CH}\right)_{2} \bullet 4 \mathrm{H}_{2} \mathrm{O}$ are placed in a very clean $250 \mathrm{~mL}$ borosilicate round bottom flask which is held with a metal clamp. The flask is heated with swirling over a Meeker burner flame for about $2 \mathrm{~min}$. It should be cooled appropriately (e.g. on a wire gauze) before handling. The bright copper mirror can be removed with nitric acid. 


\section{Discussion}

In the lecture demonstration, copper(II) formate is decomposed in a round bottom flask using the heat from a Meeker burner. During the reaction, which takes about 2 minutes with continuous swirling, the blue-green copper compound first becomes a royal blue color, then liquefies and effervesces with the release of the hydration water. Suddenly the residue becomes dark as the metal is liberated. At about the same time the gas evolved will usually support a small green flame above the neck of the flask. The flame is presumably due to the combustion of carbon monoxide, but the green color is associate with copper(II) ions (begging a discussion of fireworks colorants). The flame can be blown out and will spontaneously reignite, amusingly. Soon thereafter a highquality copper mirror develops on the inside surface of the flask. Given the unique color of copper metal, the highly reflective mirror is readily identifiable as copper. The mirror that is produced will behave as would any fresh preparation of copper. For examples, it can be converted to a blue solution of $\mathrm{Cu}\left(\mathrm{NO}_{3}\right)_{2}$ by treatment with $\mathrm{HNO}_{3}$, and then to $\mathrm{Cu}(\mathrm{OH})_{2}, \mathrm{CuO}, \mathrm{CuSO}_{4}$ solution and back to $\mathrm{Cu}$ in the well-known copper cycle laboratory sequence (12).

\section{Hazards}

Safety glasses should be worn. Heated glass surfaces can cause burns and should be cooled for at least ten minutes before handling. The liberation of $\mathrm{CO}$ is potentially dangerous but the $\mathrm{CO}$ is spontaneously combusted during the experiment. Although a fume hood is not necessary, care should be taken not to breathe the gases liberated during 
the experiment. A fire extinguisher should be readily available for this demonstration.

\section{Acknowledgements}

This work was supported by the National Science Foundation under CHE0848109. Grateful acknowledgement is also made to the donors of the American Chemical Society Petroleum Research Fund (44891-B3).

\section{Literature Cited}

1. Sheeran, D. Angew. J. Chem. Educ. 1998, 75, 453-456.

2. O'Klatner, B. L.; Rabinovich, D. J. Chem. Educ. 2000, 77, 251-252.

3. Osella, D.; Ravera, M.; Soave, C.; Scorza, S. J. Chem. Educ. 2002, 79, 343-344.

4. Sanger, M. J.; Geer, K. J. Chem. Educ. 2002, 79, 994-996.

5. Sago, S. G. J. Chem. Educ. 2004, 81, 530-531.

6. Yee, G. T.; Eddleton, J. E.; Johnson, C. E. J. Chem. Educ. 2004, 81, 1777-1779.

7. Rosenhein, L. D. J. Chem. Educ. 2001, 78, 514-515.

8. Thomas, N. C.; Faulk, S. J. Chem. Educ. 2008, 85, 817-818.

9. Körösy, F. Nature 1947, 160, 21.

10. Pike, R. D.; Starnes, W. H., Jr.; Jeng, J. P.; Bryant, W. S.; Kourtesis, P.; Adams, C. W.; Bunge, S. D.; Kang, Y. M.; Kim, A. S.; Kim, J. H.; Macko, J. A.; O’Brien, C. P. Macromolecules 1997, 30, 6957-6965.

11. Weissenhorn, R. G. Prax. Naturwiss., Chem. 1990, 39, 38. 
12. Postma, J. M.; Roberts, J. L.; Hollenberg, J. L. Chemistry in the Laboratory $6^{\text {th }}$ ed.; W. H. Freeman: New York, 2004; Expt. 5.

\section{Supporting JCE On-Line Material}

A video of the demonstration. 